\title{
Equilibrium fractionation of \\ transition metal stable isotopes during granite differentiation
}

\author{
MADELEINE A STOW, JULIE PRYTULAK, MADELEINE \\ C S HUMPHREYS AND GEOFF M NOWELL
}

Durham University

Presenting Author: madeleine.a.stow@durham.ac.uk

Granitic rocks (s.l.) make up the majority of the continental crust, but the precise differentiation mechanism(s) and magmatic conditions of granite formation are debated. Transition metal stable isotopes have the potential to assess these contrasting processes, and the T-X- $f \mathrm{O}_{2}$ conditions that may generate I-, Aand S-type granites [e.g. 1]. Most previous studies attempt this by analysing the isotopic composition of whole rock powders. While this approach may be appropriate for crystal poor lavas, many granitic rocks are coarse grained with complex textures including primocryst phases, and phases crystallised from trapped interstitial melt. Hence, whole rock composition is not representative of a true melt composition, and neighbouring phases have not necessarily crystallised in equilibrium with each other.

Here we combine petrographic examination with isotopic analysis of redox-sensitive (Fe, V) and redox-insensitive ( $\mathrm{Zn}$ ) elements in both mineral separates and whole rock powders from the well characterised Boggy Plain pluton, SE Australia [2]. The pluton is concentrically zoned and interpreted to follow simple closed system fractional crystallisation of a calc-alkaline magma [2]. Magma T-P-X- $f \mathrm{O}_{2}$ has previously been determined throughout the pluton [2], allowing us to assess the response of each isotopic system to variation in these parameters during differentiation. Primocrysts and interstitial phases were petrographically identified, alongside evidence for (dis)equilibrium amongst phases.

Mineral separates have indistinguishable $\mathrm{Zn}$ isotopic compositions, with the exception of one isotopically heavy biotite separate from an aplite, perhaps affected by late-stage fluid circulation. For $\mathrm{Fe}$ isotopes, $\delta^{56} \mathrm{Fe}_{\text {magnetite }}>\delta^{56} \mathrm{Fe}_{\text {biotite }}=$ $\delta^{56} \mathrm{Fe}_{\text {hornblende. }}$. For $\mathrm{V}$ isotopes, $\delta^{51} \mathrm{~V}_{\text {biotite }}>\delta^{51} \mathrm{~V}_{\text {hornblende }}>$ $\delta^{51} \mathrm{~V}_{\text {magnetite }}$. Whole rock Fe and $\mathrm{V}$ isotopic compositions do not co-vary during fractional crystallisation. Rayleigh models demonstrate that variations in whole rock composition are driven by the balance between crystallisation of isotopically heavy and light phases. Therefore, although whole rock analyses do not appear to provide direct information about intensive parameters during granite differentiation, the inter-mineral $\mathrm{Fe}$ and $\mathrm{V}$ fractionation factors between magnetite and silicate phases may reflect $\mathrm{T}-\mathrm{fO}_{2}$ conditions. Hence, transition metal stable isotopes may be a useful tool to understand petrogenetic conditions during granite formation.

[1] Foden et al. (2015), Lithos 212, 32-44

[2] Wyborn (1983) PhD Thesis 